Studies in African Linguistics

Volume 37, Number 1, 2008

\title{
A TEMPLATIC APPROACH TO GEMINATION IN THE IMPERFECTIVE STEM OF TASHLHIYT BERBER*
}

\author{
Mohamed Lahrouchi \\ CNRS - University Paris 8
}

\begin{abstract}
Tashlhiyt Berber uses, among other processes, gemination to form the imperfective. Most accounts of this phenomenon make reference to syllabic or prosodic structure. In this paper, I diverge from this trend, claiming that imperfective gemination is better analyzed as a templatic-based phenomenon resulting from morphological activity at the skeletal tier. I will argue for the use in the imperfective of a fixed-shape template over which consonant gemination is realized. Moreover, I will show that tri-, bi- and monoconsonantal verbs share the same template. The surface irregularity that bi- and monoconsonantal verbs display is viewed as the consequence of the identification of templatic positions.
\end{abstract}

In Tashlhiyt Berber,' three processes are involved in the formation of the imperfective:

(1) a. the gemination of a consonant in the base

b. the prefixation of the augment $t$ -

c. the insertion of a vowel in the base

* I am grateful for suggestions, comments and criticisms from the following people: the editor, the anonymous referees, J. Lowenstamm, J. Brandão de Carvalho, X. Barillot and B. Copley. All remaining errors are of course my own.

1 Tashlhiyt is one of the three main dialects of Berber spoken in Morocco. In this language, facts may differ by dialect or even inside the same dialect. The variety of Tashlhiyt we are dealing with here is the one spoken in Agadir, in the south-west of Morocco. 
Some examples ${ }^{2}$ are given in (2) to illustrate these processes:

(2)

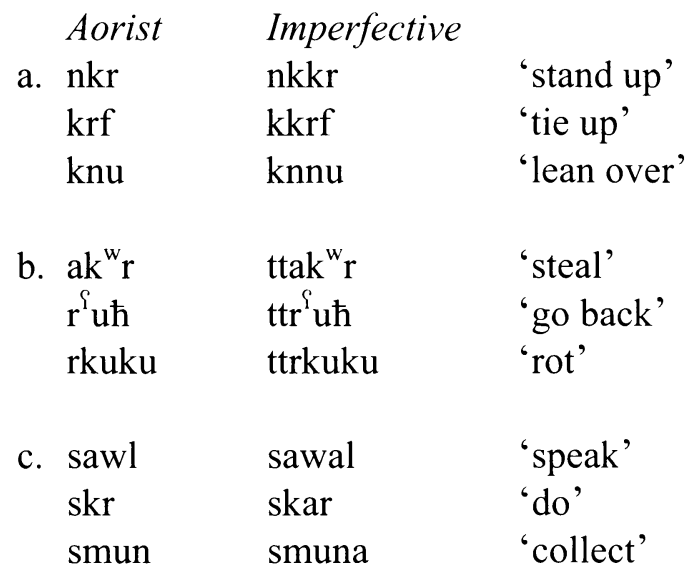

Vowel insertion may operate jointly with prefixation or with gemination to form the imperfective (e.g. gawr $\rightarrow$ ttgawar 'sit', gn $\rightarrow$ ggan 'sleep'), whereas gemination never combines with prefixation except for few mono-consonantal verbs such as $g \rightarrow \operatorname{tgga}$ 'be'.

In this paper, we will focus on the process exemplified in (2a). Attention will be drawn to the templatic mechanism underlying gemination in the imperfective. We shall try to answer the questions, how does gemination operate in the imperfective, and what is the nature of the morphological unit that underlies that operation?

Most accounts of gemination in the imperfective (Dell \& Elmedlaoui 1988, 1991, 2002; Jebbour 1996, 1999; Bensoukas 2001; MacBride 2004) make reference to syllabic or prosodic structure. In this paper (see also Louali \& Philippson 2003), I diverge from this trend, claiming that this process is better analysed as a templatic-based phenomenon resulting from morphological activity at the skeletal

\footnotetext{
2 No schwa appears in my transcription. The existence of schwas in Tashlhiyt Berber is controversial. For authors such as Coleman (1996, 2001) and Puech \& Louali (1999), epenthetic schwas appear between consonants to fill nuclei that would otherwise be empty (in Tamazight Berber, they are even treated as underlying vowels, see Saib 1976). For others such as Dell \& Elmedlaoui (2002) and Ridouane (2003), these schwas are not epenthetic but mere transitions between consonants. We will not go into this issue as it will not affect the analysis proposed here.
} 
tier in the sense of McCarthy $(1979,1981)$. It is proposed that triconsonantal verbs geminate their consonant in the imperfective by use of a fixed-shape template composed of four CV units. It is also proposed that mono- and biconsonantal verbs use the same template. Their surface irregularity is construed as the straightforward result of the identification of templatic positions.

The paper is organized as follows. In section 1, I briefly survey some principles of Templatic Morphology. In section 2, I present the data. Then, important attempts at understanding geminated imperfective in Tashlhiyt Berber are discussed in section 3. My own analysis is provided in sections 4 to 6 . Then, it is generalized in section 7 to other languages in the Berber family. Section 8 concludes the paper.

\section{Templates.}

1.1. Classical Arabic verb conjugation. Classical Arabic is probably the best known templatic language. Well before McCarthy's work (1979, 1981), which argues for the morphological role of the skeletal tier in Classical Arabic verb conjugation, linguists of the Middle Ages such as Sibawayh used fa fal 'to do' as a template model for derivation. The novelty with McCarthy is the way he extends the proposal of autosegmental phonology to Classical Arabic verbal conjugation. He indeed shows that the various forms of the verb are obtained in a natural way from the association of a consonantal root with vocalic melodies to prosodic templates.

In order to reduce the number of templates proposed by McCarthy (1979: 135, 1981: 386), Guerssel \& Lowenstamm (1990) and Lowenstamm (2003) suggest that the verbal forms of Classical Arabic are derived by means of a single template, composed of four $\mathrm{CV}$ units. ${ }^{3}$ The template is given below in (3):

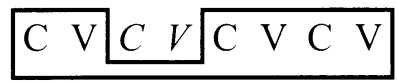

\footnotetext{
3 The idea of reducing the number of templates in the verbal conjugation of Classical Arabic is not new. McCarthy (1979: 135) has already suggested expressing the regularities that the verbal forms and their canonical patterns show by means of two templates: $\mathrm{CV}((\mathrm{CV})[+$ seg $]) \mathrm{CVC}$ and $\mathrm{CCV}([+\mathrm{seg}]) \mathrm{CVC}$. The first template abbreviates the patterns CVCVC, CVCCVC, CVVCVC, CVCVCCVC and CVCVVCVC. The second one abbreviates the patterns CCVCVC, CCVCCVC and CCVVCVC.
} 
Two observations are in order. First, the template consists of strictly alternating $\mathrm{C}$ and $\mathrm{V}$ positions. The reader is referred to section 4.1 below and references therein for an outline of the CVCV approach to syllable structure. Second, the template is made of two components: the italicized syllable is a derivational site that serves as the morphological head of the form, and the boxed syllables constitute the complement of the head. ${ }^{4}$ These components are filled one after the other by means of two operations, namely root formation and verb derivation. The first operation involves the association of root consonants and vocalic melody with the boxed $\mathrm{CV}$ positions. Then, verb derivation involves the identification of the derivational site by means of consonant or vowel spreading. Thus for example, forms II and III of the root $\sqrt{ } k t b$ 'write' are derived as shown in (4).

a.

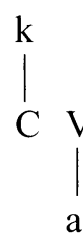

a

[kattaba] b.

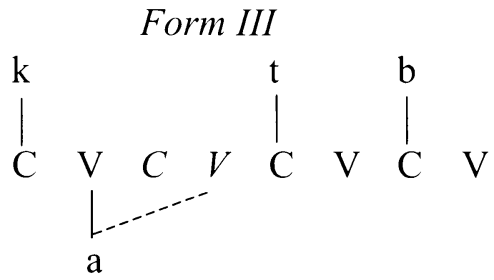

[kaataba]

The root consonants $k t b$ are connected with their slots and the vocalic melody /a/ is added. Then, the medial consonant / $/$ geminates by use of the empty $\mathrm{C}$, and the vowel /a/ spreads into the empty $\mathrm{V}$, leading to kattaba 'he made write' in (4a) and kaataba 'he corresponded' in (4b). The distinction in Classical Arabic between the root-formation and verb-derivation phases is characterized, according to Lowenstamm (2003: 22), by the direction of association. In the first phase, the association of segments to the complement (i.e. the boxed positions) proceeds in

${ }^{4}$ The head-complement structure refers to the traditional intuition that words, like sentences, are composed of elements that are associated with a single element, the head, which determines the fundamental properties of the complex. In Semitic languages where prosodic templates play a central role, the head of the template is assumed to determine certain grammatical properties of the output.

On Head and Complement in syntax, the reader is referred to X-bar theory, built on the proposal of Chomsky (1970). Similar structures are used in phonological theory such as in Dependency Phonology (Anderson 1985, 2002, Anderson \& Ewen 1987), Government Phonology (Kaye, Lowenstamm \& Vergnaud 1985, 1990) and Metrical Phonology (Hammond 1984, Prince 1985). 
the usual manner from left to right, ${ }^{5}$ whereas in the second phase the direction of spreading is determined by the position of the head (i.e. the italicized CV) with respect to the neighbouring segments: spreading is left to right in kaataba and the opposite in kattaba. ${ }^{6}$ With such a structure, Guerssel \& Lowenstamm (1990) and Lowenstamm (2003) aim to show that the association of segments with skeletal positions cannot be reduced to purely phonological conditions. Rather, they must be determined by some morphological conditions that allow identifying root positions in the template before $\mathrm{C}$ - or V-spreading is performed. ${ }^{7}$

In addition, the proposed template not only offers the tools needed to account for a range of morphological operations internal to the word, but also contributes a perspective on the theory on the phonology-syntax interface, where the prosodic units that constitute the template may project syntactic nodes. Such a hypothesis has been recently investigated in works by Bendjaballah \& Heiden (2003 and 2005 on Berber and German), Kihm (2006 on Classical Arabic) and Rucart (2006 a,b on Afar). ${ }^{8}$

1.2. Berber template morphology. The templatic character of the morphology of Berber languages is not as well established as it is in Semitic languages, in spite of important studies (see Guerssel 1992, Bendjaballah 1999, Idrissi 2000 and Lahrouchi 2003) showing that various phenomena such as causatives, inchoatives, reciprocals, passives, negative preterit and internal plurals are better analysed in terms of templatic processes (see also Jebbour 1988, Iazzi 1991, Moktadir 1989 and Dell \& Elmedlaoui 1992 for alternative analyses of the same aspects). The imperfective forms given in (2a) are similar to Classical Arabic ver-

${ }^{5}$ This allows associating the root of biconsonantal verbs such as madada to the complement before the corresponding forms II maddada and III maadada are derived.

${ }^{6}$ The well-known phenomenon of compensatory lengthening supports the universal tendency for vowels to spread in the opposite direction of consonants: vowels tend to spread to the right into the following empty slot while consonants spread to the left into the preceding empty slot (see Ingria 1980 and Meillet \& Vendryes 1963 on Latin, Sezer 1986 on Turkish and Kenesei, Vago \& Fenyvesi 1998 on Hungarian).

${ }^{7}$ In the analysis of gemination in the imperfective of Tashlhiyt Berber, which is the topic of this paper, I will assume, following Yip (1988), that the mapping of segments onto the template proceeds from the edges inward (see section 4.3 below). Further discussions about standard association conventions are given in Dwyer (1978), Hoberman (1988), Odden (1988) and Yip (1988), among others.

${ }^{8}$ Other works investigate the role of the template in syntax (see Banksira 1999 and Lumsden \& Halefom 2003). 
bal form II. They suggest the existence in Tashlhiyt Berber of a fixed-shape template over which consonant gemination is realized. Though gemination in the imperfective of Tashlhiyt Berber is in an infixed position - it involves either the initial consonant $(k r f \rightarrow k k r f)$ or the medial consonant $(n k r \rightarrow n k k r)$ - it shows one regularity: imperfectives where the final consonant is geminated ( $m r d \rightarrow$ $*_{m r d d}$ are excluded. In subsequent sections, I demonstrate two points. First, all verbs that form their imperfective by means of gemination involve the mapping of a root onto a quadrisyllabic template whose second syllable is a derivational site. Second, mono- and biconsonantal verbs use the same template as triconsonantal verbs to form their imperfective. These verbs will prove crucial to my demonstration. They are viewed in the Berber literature as irregular in that they use more than one morphological operation to derive their imperfective: e.g. $n u$ $\rightarrow$ nwwa 'cook', $g \rightarrow$ tgga 'be', $u t \rightarrow$ kkat 'beat', gn $\rightarrow$ ggan 'sleep'. I will show that their alleged irregularity hides an underlying regular mechanism: identification of templatic positions. However, I will not discuss the origin of the operations they use.

\section{Data.}

As an imperfectivizing mechanism in Tashlhiyt Berber, gemination concerns verbs containing no more than three consonants and no full vowels ${ }^{9}$ as well as verbs with the following shapes: CCU, CCI. Consider the examples in (5):

$\begin{array}{lll}\text { Aorist } & \text { Imperfective } & \\ \mathrm{g}^{\mathrm{w}} \mathrm{mr} & \mathrm{g}^{\mathrm{w}} \mathrm{mmr} & \text { 'hunt' } \\ \mathrm{k} \int \mathrm{m} & \mathrm{k} \iint \mathrm{m} & \text { 'enter' } \\ \mathrm{lkm} & \mathrm{lkkm} & \text { 'arrive' } \\ \mathrm{nkr} & \mathrm{nkkr} & \text { 'stand up, wake up' } \\ \mathrm{msl} & \mathrm{mssl} & \text { 'fill' } \\ \mathrm{mgr} & \mathrm{mggr} & \text { 'harvest' }\end{array}$

These verbs form their imperfective by geminating the second consonant. Most triconsonantal verbs ( $71 \%$ of the data in the appendix) follow this pattern though others as in (6) geminate the initial root consonant.

\footnotetext{
${ }^{9}$ Except non-native verbs such as $x d m$ 'work', $s^{i} b r$ 'support' and $\hbar b s$ 'stop, jail', which form their imperfective by means of $t$-prefixation and vowel insertion, and causative verbs such as sgn 'put to bed' and $s g l$ 'fill up' which use only vowel insertion.
} 


$\begin{array}{lll}\text { (6) } \hbar r g & \hbar \hbar r g & \text { 'burn' } \\ \mathrm{frn} & \mathrm{ffrn} & \text { 'pick over' } \\ \mathrm{krz} & \mathrm{kkrz} & \text { 'plough' } \\ \mathrm{krf} & \mathrm{kkrf} & \text { 'tie up' } \\ \mathrm{xrb} & \mathrm{xxrb} & \text { 'scratch' } \\ \mathrm{x}^{\mathrm{w}} \mathrm{m} 3 & \mathrm{xx}^{\mathrm{w}} \mathrm{m} 3 & \text { 'scratch' } \\ \mathrm{k}^{\mathrm{w}} \mathrm{mz} & \mathrm{kk}^{\mathrm{w}} \mathrm{mz} & \text { 'scrape' }\end{array}$

The verbs in (6) reject gemination of the medial consonant. The careful reader will have noticed that the medial consonants of the group are all liquids or nasals. Interestingly, a root medial sonorant will geminate when followed by a more sonorous segment, as shown in (7).

\begin{tabular}{|c|c|c|c|}
\hline \multirow[t]{6}{*}{ (7) } & $\mathrm{knu}$ & knnu & 'lean over' \\
\hline & zru & zrru & 'delouse' \\
\hline & xlu & xllu & 'destroy' \\
\hline & rwi & rwwi & 'mix' \\
\hline & $\mathrm{kmi}$ & $\mathrm{kmmi}$ & 'smoke' \\
\hline & bsi & bssi & 'melt' \\
\hline
\end{tabular}

In addition, two groups of biconsonantal verbs can be distinguished: verbs geminating their second consonant $(8 \mathrm{a})$ and those geminating their first consonant (8b). Both groups are subject to vowel insertion.

(8)

\begin{tabular}{|c|c|c|}
\hline a. $\mathrm{ns}$ & nssa & 'stay overnight' \\
\hline $\mathrm{nz}$ & nzza & 'be sold' \\
\hline $\mathrm{kl}$ & klla & 'spend the day' \\
\hline$z^{i} r$ & $z^{i} \mathrm{rra}$ & 'see' \\
\hline ls & lssa & 'wear' \\
\hline b. gn & ggan & 'sleep' \\
\hline gl & ggal & 'dry up' \\
\hline $\mathrm{fl}$ & ffal & 'leave, let' \\
\hline $\mathrm{dl}$ & ddal & 'cover' \\
\hline$d^{\uparrow} r$ & $\mathrm{tt}^{\mathrm{S}} \mathrm{ar}$ & 'fall' \\
\hline
\end{tabular}

In the following section, I briefly review earlier attempts at handling the facts just described. 


\section{Earlier Accounts of the Geminated Imperfective.}

Earlier treatments of gemination in the imperfective have relied on the idea that prior syllabification is necessary for the explanation of the phenomenon (cf. Dell \& Elmedlaoui 1988, 1991, 2002; Jebbour 1996, 1999, Bensoukas 2001 and MacBride 2004). This section reviews the main proposals made therein.

3.1. Dell \& Elmedlaoui (2002). Dell \& Elmedlaoui draw up a list of conditions that each verb in Imdlawn Tashlhiyt Berber should satisfy in order to undergo gemination in the imperfective, stating (p. 118) "a. the basic stem contains three segments none of which is a geminate; $b$. if the basic stem contains a vowel, that vowel must be the last segment". Then they make use of the following syllable rule (p. 119): "the segment which is geminated in the imperfective stem is that segment which is an onset in the basic stem". ${ }^{10}$

The examples in (8), borrowed from Dell \& Elmedlaoui (2002: 118), illustrate their hypothesis.

\begin{tabular}{|c|c|c|}
\hline Perfective & Imperfective & \\
\hline $\mathrm{k} \underline{\mathrm{r} Z}$ & $\mathrm{kkrz}$ & 'plough' \\
\hline xñ & xxng & 'strangle' \\
\hline$z^{i} \underline{l m}$ & $\mathrm{zz}^{\uparrow} \mathrm{lm}$ & 'peel' \\
\hline $3 . \bar{b} \underline{d}$ & 3bbd & 'draw' \\
\hline В.ml & вmml & 'mould' \\
\hline$x \cdot s \underline{i}$ & xssi & 'extinguish \\
\hline
\end{tabular}

The underlined segments in the first column mark syllable nuclei. The period indicates the syllable boundary. In the first three verbs, it is the first consonant which is an onset, while in the other three it is the second consonant.

Dell \& Elmedlaoui's analysis relies entirely on the information provided by their syllabification algorithm. This algorithm states that in Imdlawn Tashlhiyt Berber any segment can act as a syllable nucleus if it is the most sonorous segment ${ }^{11}$ in the syllabification domain: for instance, $r$ is the syllable nucleus in $k r z$ because it is more sonorous than $k$ and $z$. In $z b d, 3$ stands for the nucleus of the first syllable, while the remaining segments form another syllable where $d$ is the

\footnotetext{
${ }^{10}$ See also Dell \& Elmedlaoui $(1988,1991)$.

${ }^{11}$ Dell \& Elmedlaoui (2002: 76) assume the following sonority scale where segments are ranked in a decreasing sonority ordrer: $a$, high vocoids, liquids, nasals, fricatives, stops.
} 
nucleus and $b$ the onset. Without the information provided by the syllabification algorithm it would be impossible to identify the targeted segment in the imperfective.

3.2. Jebbour (1999). This author argues that syllable weight has a central role in determining the verbs that undergo gemination in the imperfective. Within a moraic approach à la Hayes (1989) he proposes that for any verb to resort to gemination in the imperfective the output must contain two light syllables (i.e. two moras).

His analysis disputes Dell \& Elmedlaoui's conception of syllable weight, specifically the lack in their syllabification algorithm of a distinction between syllables with a vowel as their nucleus and those with a consonant. He has noticed that their analysis of geminated imperfective fails to explain why CVC, VCC and VCV verbs reject gemination in the imperfective. According to him, Dell \& Elmedlaoui's statement that each verb must not contain a vocoid in a non-final position for it to undergo gemination

is curious in two regards: first, it is nothing else than the formulation of surface characteristics of geminating bases; second it needs to make reference both to the segmental composition and the syllabic make-up of the base. [p.107]

This problem, Jebbour argues, is a direct consequence of their model of syllabification that states that $\mathrm{C} \underline{\mathrm{C}}$ verbs have the same syllabic structure as $\mathrm{C} \underline{\mathrm{V}} \mathrm{C}$ verbs, and $\underline{C} . C \underline{C}$ verbs are the same as $\underline{\mathrm{V}} . \mathrm{C} \underline{\mathrm{V}}$ verbs (the underlined segments mark syllable nuclei).

The key to understanding why $\mathrm{CVC}, \mathrm{VCC}$ and $\mathrm{VCV}$ verbs fail to geminate in the imperfective relies, according to Jebbour, on the constraint that requires that the output to gemination in the imperfective contains exactly two light syllables. As shown in the table in (10), only the output of CCC and CCV verbs obeys such a constraint: 


\begin{tabular}{|c|c|c|c|}
\hline Verb base & Onset gemination & Syllabic structure & Type of syllables \\
\hline a. frs & ffrs & f.frs $\underline{C} . O{ }_{C} C^{12}$ & LL \\
\hline fsr & fssr & fs.sr $\bar{O} \underline{C} . \bar{O} \underline{C}$ & LL \\
\hline gru & grru & gr.ru OCE.OE & LL \\
\hline b. mun & $*_{\text {mmun }}$ & m.mun $\underline{C} . \mathrm{OV}$ C & $*_{\mathrm{LH}}$ \\
\hline $\mathrm{amr}$ & *ammr & am.mr $\underline{\mathrm{V}} \cdot \overline{\mathrm{O}} \underline{\mathrm{C}}$ & $*^{*} \mathrm{HL}$ \\
\hline aru & *arru & ar.ru $\underline{\mathrm{VC}} . \mathrm{OV}$ & $* \mathrm{HL}$ \\
\hline
\end{tabular}

The verb bases in (10a) undergo gemination since the resulting imperfective has two light syllables. In contrast, those in (10b) cannot geminate because their output would not have the LL syllabic pattern.

However, as noticed by Dell \& Elmedlaoui (2002:123), Jebbour's weightsensitive analysis still has problems. It fails to account for the imperfective of biconsonantal verbs that use gemination despite the fact that they contravene the LL syllable pattern (e.g. $g n \rightarrow$ ggan 'sleep', $f l \rightarrow f f a l$ 'leave, let', $d r^{\zeta} \rightarrow t t a r^{\zeta}$ 'fall' and $d^{\prime} i \rightarrow t t^{\prime} a y$ 'take out'). Note that biconsonantal verbs raise another type of problem regarding Dell \& Elmedlaoui's analysis. It fails to explain why these verbs use both gemination and vowel insertion to form their imperfective (see section 6 below).

3.3. Bensoukas (2001). Like Jebbour, Bensoukas adopts Dell \& Elmedlaoui's hypothesis that vowelless syllables have consonantal nuclei. His Optimality Theoretic account ${ }^{13}$ begins with the observation that gemination is in complementary distribution with $t t$ - prefixation in the imperfective. Then, he proposes that "imperfective formation in Tashlhiyt consists in affixing a consonantal mora to the verb root" (p. 122). This affixation is claimed to be the underlying morpheme of the imperfective. $t t$ - prefixation ${ }^{14}$ and gemination are merely variant realizations of this morpheme. The choice of either realization relies, according to

\footnotetext{
${ }^{12}$ The underlined segment stands for the nucleus and $\mathrm{O}$ stands for the onset. The second syllable in frs (OCC) is analyzed by the author as a light syllable whose last $C$ does not count in weight. It can be linked either to the preceding $\mu$ or directly to the node $\sigma$ (see Jebbour 1999: 104).

${ }^{13}$ See MacBride (2004) for an alternative account of the facts within the framework of OT.

${ }^{14}$ Bensoukas assumes, on the basis of Hayes (1989) and Davis $(1995,1999)$ among others, that geminates are underlyingly mono-moraic. The prefix $t t$ - in the imperfective is thus counted as mono-moraic.
} 
the author, on the interaction of specific well-formedness constraints: (i) a bimoraicity constraint, similar to that proposed in Jebbour (1999), which is responsible for the choice between gemination and $t t$ - prefixation, and (ii) a sonority contour constraint that determines which consonant geminates in the verb. The first constraint prevents CCC and CCV verbs from using the prefix $t t$-. The second constraint chooses the candidate that has the optimal sonority contour: for instance, in the case of competing candidates such as $k k r z$ and $k r r z$, the sonority contour of the syllable $k r z$ in the first form (syllabified as $k . k r z$ ) is preferred to that of the syllable $r z$ in the second form (syllabified as $k r . r z$ ).

In sum, the syllable-based approaches to geminated imperfective as stated in Dell \& Elmedlaoui (1988 and 2002) and amended in Jebbour (1999) and Bensoukas (2001) focus on characterizing the kind of interrelation that exists between prosody and morphology in Tashlhiyt Berber. They predict the correct output for almost all triconsonantal verbs, but they leave out mono- and biconsonantal verbs such as $g$ 'be', $k k$ 'pass by', $\iint$ 'eat' and $r g$ 'grind, stone' which are morphologically complex, using gemination and affixation to derive tgga, tkka, ftta and rrag respectively. The authors show among other things how the geminated consonant is selected in the base, but the relation that may exist between gemination as a derivational device and the syllabic status of segments is left as an open question. In addition, their analyses limit themselves to the case of Tashlhiyt Berber where the gemination involves either $\mathrm{C}_{1}$ or $\mathrm{C}_{2}$. Once extended to Berber languages other than Tashlhiyt (see section 7 in this paper), their analysis becomes unnecessarily complicated, since the geminated consonant is invariably $\mathrm{C}_{2}$ regardless of its syllabic status. In my own account, I will try to bring out more explicitly the templatic mechanism responsible for gemination as well as the relationship between consonant gemination and the structure of the template.

\section{Templatic Account of Gemination.}

This section outlines the main assumptions about the representation of the skeletal tier and the syllable structure in the framework of Government Phonology.

4.1 CVCV model. All examples handled in this paper use the CVCV model (Lowenstamm 1996), which falls within the framework of Government Phonology as outlined in Kaye, Lowenstamm \& Vergnaud $(1985,1990)$. This approach to syllable structure stipulates that the skeletal level of phonological representations consists of strict alternations of onset and nucleus positions, i.e. $\mathrm{C}$ and $\mathrm{V}$ positions. Only consonantal segments are linked to $\mathrm{C}$ positions and only vocalic 
segments appear in $\mathrm{V}$ positions. Moreover, within this model, different surface syllable types such as a 'closed syllable', a 'branching onset', a 'branching nucleus' and a 'geminate' share the same skeletal material: two CV units.
a. closed syllable

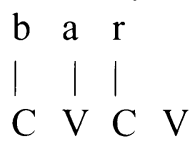
[bar]
c. branching onset

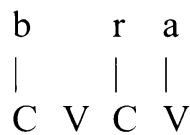
[bra]

b. branching nucleus

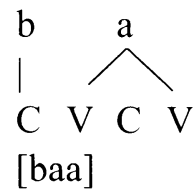

d. geminate

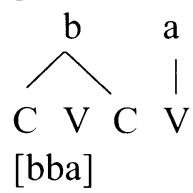

The differences in the surface syllabic structures obtained in (11) lie in the way segments are associated to the skeletal tier:

a. The geminate in (11d) has an empty $\mathrm{V}$ position between its members whereas the long vowel in (11b) contains an empty $C$ position.

b. The branching onset in (11c) has an empty $\mathrm{V}$ between its consonants.

c. The consonant located in the coda of the surface closed syllable in (11a) appears in the onset of the second syllable whose nucleus is empty.

Skeletal positions that have no phonetic realization are said to be licensed to remain empty by virtue of the government relation that they share with the neighbouring segments. Proper Government is one such relation which allows a vocalic position to remain empty when followed by a vowel. This particularly accounts for the distribution of schwas and the well-known V/Ø alternation such as in Moroccan Arabic køtab 'he wrote', where the V position between / $\mathrm{k} /$ and $/ \mathrm{t} /$, properly governed by the schwa that appears between $/ \mathrm{t} / \mathrm{and} / \mathrm{b} /$, remains empty opposed to katøbu 'they wrote', where the same V position, non-governed, surfaces as schwa (see Kaye 1990). The same phenomenon occurs in certain Berber varieties such as Kabyle Berber: for instance, the vocalic position between /X/ and /ð/ remains empty in хøðəm 'work!' but not in хәдøтәь 'I worked'. Interestingly, this position is properly governed by the following schwa in the first form but not in the second one (see Bendjaballah 2001: 188). For more 
details about this model, the reader will refer to the work mentioned above and Scheer (2004).

4.2 Representation of Berber peripheral vowels. In Kabbaj (1990), Bendjaballah (1999, 2001) and Idrissi (2000), it is argued on the basis of Lowenstamm's hypothesis (1991) about the vocalic system of Maghribi Arabic and EthioSemitic, that the peripheral vowels of Berber are associated with 'branching nuclei'. The same parameter is adopted here:

(12) In Tashlhiyt Berber, peripheral vowels must be associated with two V positions.

According to this parameter, the representation of the three peripheral vowels of Tashlhiyt Berber follows under (13):

(13) skeletal level

segmental level

phonetic realization

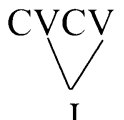

[i]

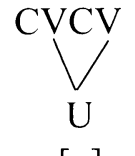

$[\mathrm{u}]$

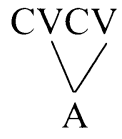

[a]

Note that the parameter in (12) is a condition on the association of vocalic elements to the skeletal level. It does not affect the segmental level. Thus, the three vowels of the language surface as short vowels, viz. [i], [a] and [u].

The correspondences between Tashlhiyt Berber and Classical Arabic endorse the above proposal. Indeed, in a number of items shared by these languages there is a regular change whereby the long vowels of Classical Arabic correspond to phonetically short vowels in Tashlhiyt Berber. Short vowels in Classical Arabic disappear in Tashlhiyt Berber. By contrast, singleton and geminate consonants in Classical Arabic are preserved as such in Tashlhiyt Berber. The examples in (14) illustrate these correspondences:

Classical Arabic Tashlhiyt Berber

a. zaahada 3ahd

'to fight'

saafara

safr

'to travel'

laahaqa

laћg

alkitaab

lktab

'to reach, pursue'

albahr

lbћr

'the book'

'the sea' 


$\begin{array}{lll}\text { b. farraqa } & \text { frrq } & \text { 'to divide' } \\ \text { Saððaba } & \text { Iddb } & \text { 'to torture' } \\ \text { Sallama } & \text { 'tlm } & \text { 'to teach' } \\ \text { fakkara } & \text { fkkr } & \text { 'to think' } \\ \text { 3azzaar } & \text { a-gzzar } & \text { 'butcher' }\end{array}$

The parameter in (12) characterizes these correspondences by distinguishing the vowels that occupy two vocalic positions from those that have access to only one position. The first surface as short in Tashlhiyt Berber, the latter disappear. For instance, in the Classical Arabic form saafara in (14a), the long vowel is associated with two vocalic positions while the remaining vowels connect to only one position. In the corresponding form in Tashlhiyt Berber, the first vowel surfaces as [a], the others remain silent (further discussion of this proposal is provided in Bendjaballah 2001: 190).

4.3 Imperfective template. In terms of templatic morphology, the imperfective of the triconsonantal verbs given in (5) and (6) is derived by means of a quadriconsonantal template that allows geminating the initial or medial consonant. For the sake of uniformity, I propose that these verbs use the same template as in Classical Arabic verb conjugation, repeated in (15) for convenience:

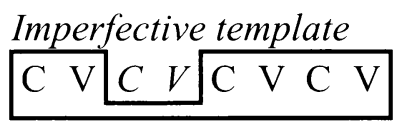

Segments are mapped onto this template from the edges inward (cf. Yip 1988). ${ }^{15}$ This direction of association predicts that if there are fewer consonants in the root than consonantal positions in the template, the medial consonant is likely to spread, since after associating the initial and final consonants with the edges of the template, the medial consonant automatically fills the remaining consonantal positions. Thus, for example, the verb $n k r$ 'stand up' gets its medial consonant geminated in the imperfective as shown in (16):

\footnotetext{
${ }^{15}$ The same direction of association is used by Moktadir (1989) in the analysis of the passive formation in Tashlhiyt Berber.
} 
(16)

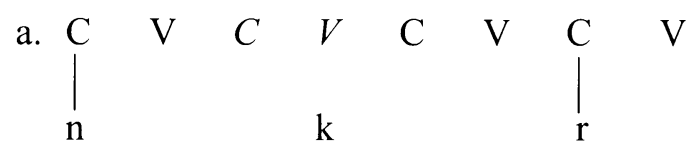
b. $\underset{\mathrm{n}}{\mathrm{C}}$
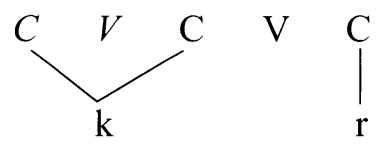
[nkkr]

In (16a), the consonants $/ \mathrm{n} /$ and $/ \mathrm{r} /$ are associated to the initial and final consonantal positions in the template. Then, in (16b), the consonant $/ \mathrm{k} /$ fills the remaining $\mathrm{C}$ positions.

The verbs given in (7) behave like those ones in (5) in that they geminate the second consonant to form their imperfective. Moreover, they display a high vocoid; $/ \mathrm{u} /$ or $/ \mathrm{i} /$ in the final position. Given the parameter in (12), these vocoids connect to two $\mathrm{V}$ positions. The imperfective form of $x l u$ 'be crazy' is represented below in (17):
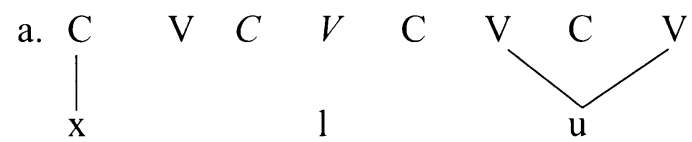

b.
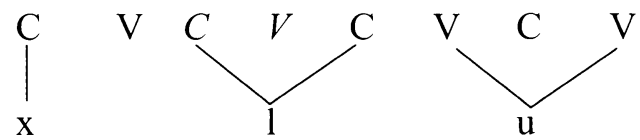

[xllu]

The first segment $/ \mathrm{x} /$ is associated to the first $\mathrm{C}$ position in the template and the last segment $/ \mathrm{u} /$ is associated to the last two $\mathrm{V}$ positions. Then, the medial consonant $/ 1 /$ geminates by use of the remaining consonantal positions in the template.

In the following section, we will see that initial consonant spreading in verbs such as in (6) is not automatic. Rather, it requires a rightward spreading rule that compensates for prohibited spreading of certain consonants in the medial position.

4.4 Sonority effect. The verbs in (6) undergo the same morphological operation as those ones in (5): they geminate one consonant by use of the template in (15). However, their particular behaviour with respect to gemination - i.e. geminating 
$\mathrm{C}_{1}$ instead of $\mathrm{C}_{2}$ - has to be explained at the phonological level. Admittedly, this is what Dell \& Elmedlaoui (1991:85) suggest: "geminate that consonant which is a syllable onset". This would be sufficient if all Berber languages geminate either $\mathrm{C}_{1}$ or $\mathrm{C}_{2}$. But apart from Tashlhiyt all other varieties invariably geminate $\mathrm{C}_{2}$. The reason why $C_{1}$ geminates in a number of imperfective forms in Tashlhiyt Berber is related to the nature of consonants that appear in the medial position. Thus, we notice that the verbs in (6) contain sonorants (liquids and nasals) in this position. One could ask if Tashlhiyt Berber prohibits geminating liquids and nasals in the imperfective. The answer appears in the examples in (7) where such consonants geminate. Therefore, another question arises: is there any phonological constraint that prohibits geminating sonorants in the verbs in (6)?

The answer to this question involves examining the segmental environment of sonorants occurring in the medial position of both groups of verbs in (6) and (7). In terms of sonority hierarchy (cf. Sievers 1881, Jespersen 1904, Clements 1990), each sonorant in the verbs in (6) is surrounded by less sonorous segments, i.e. obstruents, whereas in (7) it is followed by a more sonorous segment, i.e. a vocoid. At the same time, these sonorants geminate in (7) but not in (6). For instance, the liquid / $\mathrm{r} /$ geminates in zru 'delouse' where it is followed by a more sonorous segment, but not in $k r z$ 'plough' where it is the most sonorous segment.

The sonority hierarchy or sonority scale is a ranking of segments along a scale on the basis of their sonority. This scale explains, in particular, the organization of segments within the syllable: more sonorous segments stand closer to the peak of the syllable than less sonorous segments. In the present analysis, I am assuming the following sonority scale where segments appear in order of increasing sonority: Obstruent $>$ Nasal $>$ Liquid $>$ Glide/Vowel (see Clements 1990). In this scale, stops and fricatives are assumed to be sonorityequal. So do glides and vowels. This is all the more tenable in the first case that in Tashlhiyt Berber fricatives have no effect on determining the geminating consonant in the imperfective. That is to say, a fricative in the medial position does not imply the gemination of the preceding stop: verbs such as bsr 'spread', $\mathrm{gzm}$ 'cut' and $\mathrm{kJm}$ 'enter' geminate their medial fricative despite the fact that it is preceded by a stop. On the other hand, I assume following Angoujard (1990: 15) that gutturals $(h, h, \uparrow, ?)$ are lower in sonority than nasals, i.e. they have the same sonority as obstruents. This is supported in Tashlhiyt Berber by the imperfective of verbs that contain such consonants in the initial or medial position. Verbs such as $h r \int$ 'feel slightly ill', $\hbar r \int$ 'be smart', $\hbar r g$ 'burn', zhr 'blaze up' $m \hbar d^{l}$ 'poison' and $l \hbar m$ 'solder' form their imperfective by geminating the guttural while it is adjacent to a sonorant. They would not do so if gutturals were higher in sonority. 
Let us return now to the behavior of sonorants with respect to gemination. A phenomenon similar to that present in the imperfective of the verbs in (6) is found in the action noun formation. In Tashlhiyt Berber, nouns of this type show a uniform pattern $\mathrm{aCCaC}$ where the medial consonant is either simple or geminated, depending on its sonority. For instance, the action nouns corresponding to the verbs $r d^{\prime} l$ 'lend', bzg 'swell up' and $n t l$ 'hide' are $\operatorname{artt}^{\prime}$ al, abzzag and anttal, respectively. In contrast, the verbs $f r g$ 'tighten', $m r g$ 'be ashamed', $s r \hbar$ 'free (ebb tide)' and frn 'sort out' form their action noun as afrag, amrag, asra $\hbar$ and afran, respectively. As we can see, in the first group of verbs the medial consonant is an obstruent preceded or followed by a more sonorous segment, while in the other group it is a sonorant surrounded by less sonorous segments. In the corresponding action nouns, the first group geminates the medial consonant, and not the second group.

These facts suggest that there is a relationship of cause and effect between the sonority of segments and their behaviour towards gemination. Sonorants do not geminate in the imperfective if their neighbouring segments are less sonorous. Consequently, I propose that the following constraint is active in the imperfective derivation:

(18) Any segment is prohibited to geminate in the imperfective if it is the most sonorous segment in the root.

This constraint prevents all sonorants which appear in the medial position of the verbs in (6) from geminating. Given the configuration of the template, it is the initial consonant that geminates through spreading into the derivational $\mathrm{CV}$. The gemination of the initial consonant can thus be seen as a subsidiary operation that compensates for prohibited gemination of the medial consonant. This is somewhat similar to the strategy used in the Tiberian Hebrew morphology. In this language, a number of noun derivations involve $\mathrm{C}_{2}$ gemination as in naggar 'carpenter' and sippuur 'story'. Opposed to these forms are paaraa 'horseman' and baaheret 'white spots on skin' where the second consonant is not geminated. Instead, the preceding vowel lengthens. The same phenomenon is found in the verbal conjugation (binyanim): kitteb 'write' vs. beerak 'bless'. In fact, /r/ and /h/ belong to a class of consonants that never geminate in Tiberian Hebrew. Therefore, vowel lengthening is but a 'subsidiary' operation that compensates for prohibited gemination of certain consonants (cf. among others Gesenius 1881, Bauer \& Leander 1922 and Lowenstamm \& Kaye 1986). Note that compensatory lengthening in Tiberian Hebrew should not be understood in the sense that the 
lengthened segment compensates for the loss of another segment. Rather, lengthening occurs to preserve the number of slots in the skeleton (cf. De Chene \& Anderson 1979, Ingria 1980 and Hayes 1989 among others about the standard version of compensatory lengthening).

The imperfective form of $x r b$ 'scratch' illustrates the whole derivation.

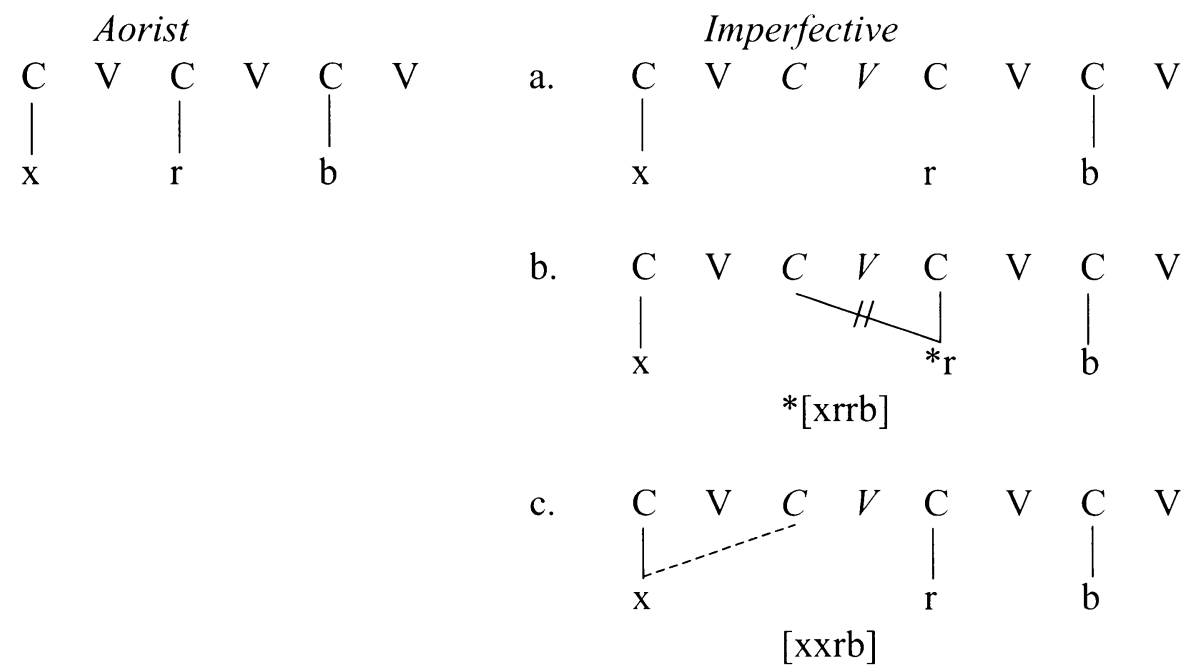

The segments are associated to the template from the edges inward. In (19b), the segment $/ \mathrm{r} /$ fails to geminate since it is the most sonorous segment in the root. The correct form geminating the first consonant $/ \mathrm{x} /$ is given in $(19 \mathrm{c})$.

However, three observations are in order. Firstly, the constraint in (18) does not necessarily imply the gemination of the least sonorous segment in the root. If this were the case, many verbs in (5) such as $g^{\prime \prime} m r$, frn, knu and $k m i$ would geminate their initial consonant. The important thing is that (18) allows the gemination of the medial consonant in any case, except when it is the most sonorous segment in the root. ${ }^{16}$ Secondly, there are few verbs such as $x w u$ 'empty', $\int w u$

\footnotetext{
${ }^{16}$ Only one counter-example to this constraint, $r w l$ 'run away', is found in the data. In the imperfective, this verb either geminates the medial glide (though it is the most sonorous segment) or surfaces with a geminated $g^{n}$ in place of geminated $w$. The latter form may suggest that $r g^{\prime \prime} l$ is the underlying form of the verb. In Dell \& Elmedlaoui's syllable-based analysis (2002), the first form, viz. $r w w l$, is analyzed with reference to ranked constraints: in the verbal base $r w l$, the medial glide is first syllabified in the onset of the second syllable by virtue of a highly ranked constraint that prohibits onsetless syllables in the non-initial position.
} 
'roast' and $z^{\Upsilon} w i$ 'left-handed' where the medial and final consonants are sonorityequal (see the sonority scale on page 36 ). These verbs all geminate the medial segment. So do the verbs that end with two obstruents such as $n \int f$ 'scrape', $n g d^{\text {' }}$ 'drown' and $n f d$ 'be stirred up' and those that begin with two obstruents such as $b d r$ 'mention', $f_{s r}$ 'spread' and $f_{s i}$ 'melt'. ${ }^{17}$ Thirdly, there exist in the language a number of verbs that are entirely made of obstruents and others that contain only sonorants. Five native verbs of the latter type are found in the data: $n r u$ 'defeat', $r w i$ 'make dirty', $r w l$ 'flee', $m l u$ 'be limp' and $r m i$ 'be tired'. Apart from $r w l$ that contradicts (18) by geminating the medial glide (see footnote 16) and $m l u$ that forms its imperfective by means of the prefix $t t$-, the remaining verbs geminate, as expected, their medial consonant. In contrast, verbs with only obstruents, such as $b d g$ 'be wet', $b z g$ 'enflate' and $z d s$ 'inhabit' (nine verbs in the data are of this type) all form their imperfective by means of $t t$-prefixation and vowel insertion. Given their segmental make up, one may expect them to undergo gemination. ${ }^{18}$

In sum, the template in (15) and the constraint in (18) ultimately allow distinguishing two classes of triconsonantal verbs:

a. verbs as in (5) that geminate the second root consonant,

b. verbs as in (6) that geminate the first root consonant.

However, both of these classes are shown to be underlyingly similar in that their consonant geminates by use of the same template, the one as in (15).

Then, it is geminated in the imperfective. Without such a constraint, the medial /w/ would have been syllabified in the nucleus and the resulting imperfective would have been *rrwl.

${ }^{17}$ Only 3 verbs that begin with two sonorants are found in the data. They are of the type NLO or LNO (where $\mathrm{N}=$ nasal, $\mathrm{L}=$ liquid and $\mathrm{O}=$ obstruent): $m r z$ 'wound', $m r g$ 'be ashamed' and $\operatorname{lm} z^{\text {' ' }}$ 'swallow without chewing'. The first verb geminates the initial consonant and the others use the prefix $t t$ - with the vowel $a$ inserted between the last two consonants.

${ }^{18}$ Dell \& Elmedlaoui (2002:119) gave the example of $f s d$ 'be spoiled' that forms its imperfective in Imdlawn Tashlhiyt Berber either by geminating the initial consonant or by prefixing $t t$ and inserting the vowel $a$ between the last two consonants. The fact that the authors "have not found more is not surprising, for there are not many CCC verbs with only obstruents." In the dialect we are examining here (see also Boumalk 2003 and El Mountassir 2003), the verb $f s d$, which is borrowed from Arabic, has only one imperfective form: $t t-f s a d$.

It is unknown why verbs of this type behave in this way. What we observe, however, is that unlike the other verbs, they do not contain any sonorant in their root. 


\section{5. tt- Prefixation and Vowel Insertion in the Imperfective.}

Before we discuss the imperfective of mono- and biconsonantal verbs, let us examine briefly the imperfective formation involving $t t$ - prefixation and vowel insertion. Some aspects of this outline fall within the analysis presented so far. As noticed in the first section, gemination and $t$ - prefixation never co-occur in the same form in the imperfective. In addition, $t t$-prefixation involves verbs whose base shows one of the following properties:

(20) a. It is vowel-initial or medial.

b. It contains a lexical geminate.

c. It contains more than three segments.

d. It is a loan word.

Moreover, the prefixation of $t t$ - is accompanied by the insertion of a prefinal vowel in verbs that end with two consonants. The inserted vowel is a copy of the preceding vowel in the base; otherwise, it is $a$. The examples in (21) illustrate these processes.

\begin{tabular}{|c|c|c|c|}
\hline $\begin{array}{l}(21) \\
\\
a .\end{array}$ & $\begin{array}{l}\text { Aorist } \\
\text { awk } \\
\text { anf } \\
\text { aru }\end{array}$ & $\begin{array}{l}\text { Imperfective } \\
\text { ttawk } \\
\text { ttanf } \\
\text { ttaru }\end{array}$ & $\begin{array}{l}\text { 'pull' } \\
\text { 'withdraw, move away' } \\
\text { 'give birth' }\end{array}$ \\
\hline b. & $\begin{array}{l}\mathrm{ddz} \\
\text { brrm } \\
\mathrm{k}^{\mathrm{w}} \mathrm{mm} \int\end{array}$ & $\begin{array}{l}\text { ttddz } \\
\text { ttbrram } \\
\text { ttk }^{\mathrm{w}} \mathrm{mma}\end{array}$ & $\begin{array}{l}\text { 'cram' } \\
\text { 'turn' } \\
\text { 'crease, crumple' }\end{array}$ \\
\hline & $\begin{array}{l}\text { bndf } \\
\mathrm{kr}^{i} \mathrm{fs} \\
\text { rfufn }\end{array}$ & $\begin{array}{l}\text { ttsndaf } \\
\text { ttkr fas } \\
\text { ttrfufn }\end{array}$ & $\begin{array}{l}\text { 'swindle' } \\
\text { 'exhaust' } \\
\text { 'go through hardships' }\end{array}$ \\
\hline $\mathrm{d}$. & $\begin{array}{l}\text { xdm } \\
\text { Sbr } \\
\text { fhm }\end{array}$ & $\begin{array}{l}\text { ttxdam } \\
\text { ttSbar } \\
\text { ttfham }\end{array}$ & $\begin{array}{l}\text { 'work' } \\
\text { 'weigh' } \\
\text { 'understand' }\end{array}$ \\
\hline
\end{tabular}

The verbs in (21a) are vowel-initial. Those in (21b) contain a lexical geminate. Quadriconsonantal verbs appear in (21c) and loan verbs are in (21d). The 
reason that verbs of this type reject gemination has been a matter of debate in the literature. One noticeable explanation, provided in Jebbour (1999) and Bensoukas (2001), makes reference to weight. The first author suggests that for any verb to undergo gemination in the imperfective it must contain two light syllables in the output. Outputs that contravene this condition resort to $t t$-prefixation. The second author proposes that gemination and $t t$-prefixation are but variant realizations of an underlying consonantal mora affixed to the verb (see section 3 above).

In the present analysis, the weight constraint can be defined in terms of the number of $\mathrm{CV}$ units that the imperfective form contains. Many of the verbs in (21) would exceed the quadrisyllabic template in (15) if their imperfective were formed by means of gemination. The forms represented in (22) illustrate this situation:

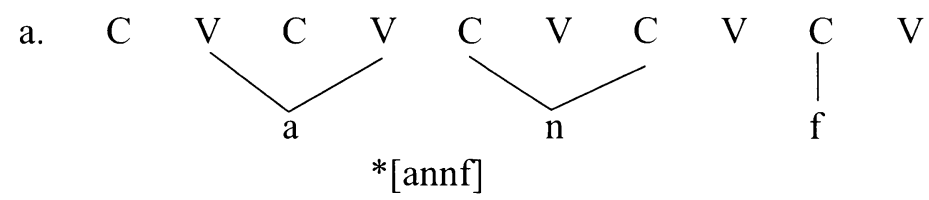

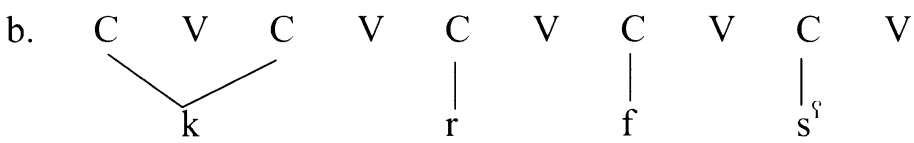

$*\left[\mathrm{kkrfs}^{\mathrm{i}}\right]$

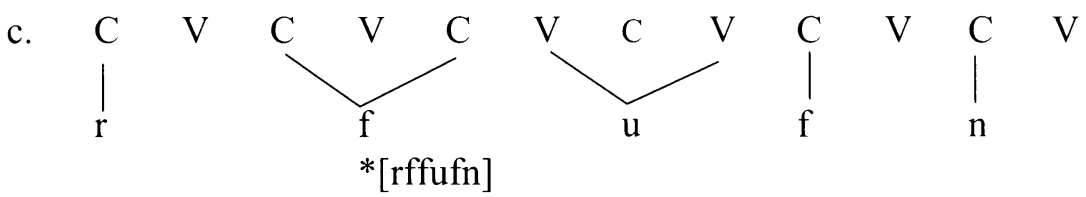

In comparison with the above verbs, many other verbs such as lu $\hbar$ 'throw', mun 'accompany', sgn 'put to bed', $s g l$ 'bury', $x d m$ 'work' and $f h m$ 'understand' use the prefix $t t$ - though their imperfective would fit the template if it were derived by means of gemination. The first two verbs, lu $\hbar$ and mun, are vowelmedial, the following two are causative and the remaining are borrowed from Arabic. An alternative analysis for mun-like verbs can hold that the branching medial vowel blocks the identification of the derivational syllable by means of consonant spreading, provided that the segments of the base are first associated to the boxed positions in the template. The situation is illustrated below in (23). 
(23)

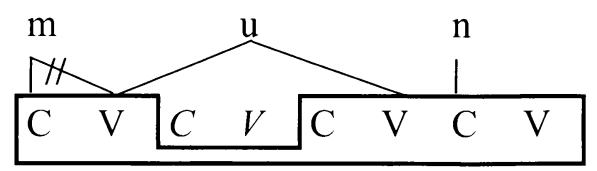

The radical vowel $/ \mathrm{u} /$ branches over the derivational syllable, thus blocking gemination of the initial $/ \mathrm{m} /$.

In the following section, we show that the irregularity of the imperfective of mono- and biconsonantal verbs results from the use of the same template as in triconsonantal verbs.

\section{The Imperfective of Bi- and Monoconsonantal Verbs.}

6.1. Biconsonantals. Verbs grouped in $(8 \mathrm{a})$ and $(8 \mathrm{~b})$ are more complex; they belong to those verbs which use more than one morphological operation to derive their imperfective. Moreover, their behaviour with respect to these operations seems to differ from one category to the next. This calls for a more extensive examination. First of all, let us examine their conjugation paradigm including the aorist, imperfective and preterit in comparison with $\mathrm{CCU}$ verbs:

\begin{tabular}{|c|c|c|c|c|c|}
\hline \multirow{2}{*}{\multicolumn{2}{|c|}{ Aorist }} & \multirow[t]{2}{*}{ Imperfective } & \multicolumn{2}{|c|}{ Preterit } & \\
\hline & & & $3 p m s$ & Ips & \\
\hline a. & ns & nssa & nsa & nsib & 'stay overnight' \\
\hline & ls & lssa & lsa & lsib & 'wear' \\
\hline & $\mathrm{nz}$ & nzza & nza & nzis & 'be sold' \\
\hline & $\mathrm{kl}$ & klla & kla & klis & 'spend the day' \\
\hline & $z^{i} r$ & $z^{i} \mathrm{rra}$ & $z^{i} r a$ & z'rí & 'see' \\
\hline b. & gn & ggan & gn & gnь & 'sleep' \\
\hline & $\mathrm{dl}$ & ddal & $\mathrm{dl}$ & dls & 'cover' \\
\hline & $\mathrm{gl}$ & ggal & $\mathrm{gl}$ & gls & 'dry up' \\
\hline & $d^{\prime} r$ & $\mathrm{tt}^{\dagger} \mathrm{ar}$ & $d^{i} r$ & $d^{\prime} r \mathrm{r}$ & 'fall' \\
\hline & $\mathrm{fl}$ & ffal & fl & fls & 'leave, let' \\
\hline
\end{tabular}




\begin{tabular}{|c|c|c|c|c|}
\hline c. $\mathrm{ml}$ & mmal & $\mathrm{mla}$ & mlis & 'show' \\
\hline SK & ssá & sьa & sьів & 'buy' \\
\hline $\mathrm{zd}^{\mathrm{i}}$ & $\operatorname{zzad}^{i}$ & $z^{i} \mathrm{a}$ & 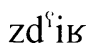 & 'grind' \\
\hline rg & rrag & rga & rgis & 'grind, stone' \\
\hline БZ & qqaz & вza & вzів & 'dig' \\
\hline d. bnu & bnnu & bna & bnis & 'build' \\
\hline $\mathrm{rbu}$ & $\mathrm{rbbu}$ & rba & rbis & 'carry in the back' \\
\hline zlu & 3llu & 3la & зlis & 'loose' \\
\hline rku & rkku & rka & rkis & 'be dirty' \\
\hline
\end{tabular}

The verbs in (24a) behave in a similar way to CCU verbs: they geminate the medial consonant. They also use the vowel $i$ in the preterit $1^{\text {st }}$ person singular, and end with the vowel $a$ in the preterit $3^{\text {rd }}$ person masculine singular. In contrast, the verbs in (24b) form their imperfective by geminating the initial consonant and infixing the vowel $a$. Their preterit merely exhibits the two radicals.

On the basis of these similarities, Iazzi (1991) has suggested that biconsonantal verbs as in (24a) contain an underlying vocalic segment that has no more than one distinctive feature, namely [+vocalic]. According to Iazzi this underlying vowel stands for an ancient segment that went out of use, revealing a state of the language where a vowel, probably $u$, occupied the final position of the verb. Certain Berber varieties (cf. Basset edition 2004: 64) actually use the vowel $u$ instead of $a$ at the Preterit 3pms: e.g. $i$-nsu 'stay overnight' in Snous, Menacer and Ouargla varieties, $i-l s u$ 'wear' in Ghadames variety, $i-r z^{i} u$ 'break' in Seghroushen, Snous, Menacer, Ouargla and Ghadames varieties, and $i-n z u$ 'be sold' in Menacer and Ouargla varieties.

An alternative explanation is proposed in Prasse (1972) and Kossmann (2002, 2003), and taken up by Louali and Philippson (2003). According to the authors, the difference between verbs infixing the vowel $a$ and those suffixing it is diachronic: it is due to the loss of a root consonant, the medial consonant in the first type of verbs and the final consonant in the second type.

Given the morphophonological similarities discussed above, I assume that biconsonantal verbs such as those in (24) are underlying trisegmental. The vowel they display in the imperfective is phonologically well motivated. It compensates for the unexpressed root segment and allows them to fit the same template as triconsonantal verbs. The imperfective form of $k l$ and $g l$ illustrate the proposal below in (25). 
(25)

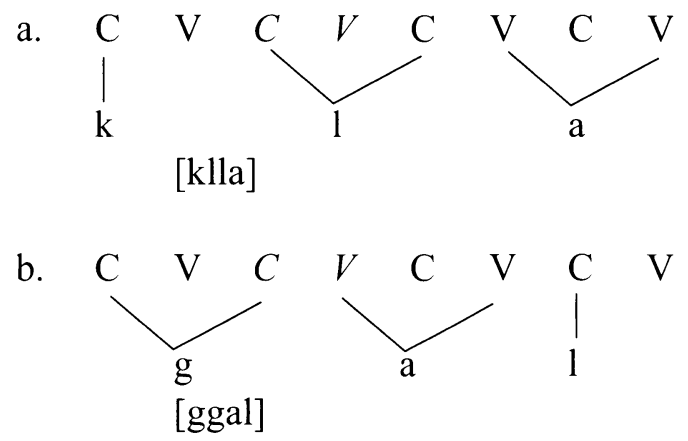

6.2 Monoconsonantals. So far we have seen that the structure of the template that bi- and triconsonantal verbs use in the imperfective causes gemination of the initial or medial consonant. In this section, we examine the imperfective formation of monoconsonantal verbs. The reader's attention is drawn to the template that their imperfective forms use.

Monoconsonantal verbs form their imperfective with a combination of different operations including affixation and gemination.

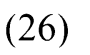

$\begin{array}{lll}\text { Aorist } & \text { Imperfective } \\ \mathrm{g} & \operatorname{tgga} 19 & \text { 'be, become' } \\ \iint_{\mathrm{n}} & \int \mathrm{tta} & \text { 'eat' } \\ \mathrm{nu} & \text { nwwa } & \text { 'cook' } \\ \mathrm{fi} & \mathrm{tfay} & \text { 'suppurate' } \\ \mathrm{B}^{\mathrm{w}} \mathrm{i} & \mathrm{qq}^{\mathrm{w}} \text { ay } & \text { 'catch' } \\ \text { ав } & \text { tав } & \text { 'bark' }\end{array}$

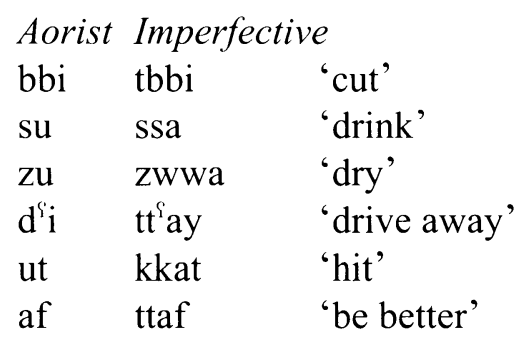

Traditionally, linguists who have examined these kinds of formations have often been discouraged by the number and nature of the operations used to form imperfectives. Indeed, we distinguish different types of verbs in these examples:

\footnotetext{
${ }^{19}$ In Tashlhiyt Berber, there is a dialectal variation as to the shape of the prefix that monoconsonantal verbs use in the imperfective. For example, the imperfective forms of the verbs $g$ 'be', $k k$ 'pass through', $d d u$ 'go' and $b b i$ 'cut' are given with a non-geminated prefix in the dialect described in Elmoutassir (2003), whereas in the dialect described in Boumalk (2003) they are given with a geminated prefix. In other Berber varieties such as Tamashek, the prefix is always non-geminated: e.g. t-ázz 'do', t-áræbba 'raise young', t-íru 'bray' (cf. Heath 2004).
} 
i. a verb using gemination, vowel insertion and prefixation (tgga)

ii. verbs using both gemination and vowel insertion ( $s s a, t t^{i} a y, q q^{n \prime} a y$ )

iii. a verb using both prefixation and vowel insertion (tfay)

iv. verbs using vocalic and consonantal insertion ( $\mathrm{ftta}, \mathrm{kkat})$

v. verbs using only prefixation $(t d d u, t b b i, t t a s, t t a f)$

The verbs $n u$ and $z u$ behave differently, and are analysed as underlying biconsonantal. Their second consonant is a glide $/ \mathrm{w} /$ that surfaces as $[\mathrm{u}$ ] wordfinally and preceded by a consonant (see also /y/ which surfaces as [i] in $\mathrm{kmi}$ 'smoke' and $d^{\S} i$ 'drive away-aorist' but as [y] in akmmay 'smoker' and $t t^{\text {' } a y ~}$ 'drive away-imperfective'). In addition, the vowel $u$ in $s u$ 'drink', which alternates with $a$ in the imperfective, seems to be a lexical vowel. Most linguists treat glides and high vowels in Berber as phonetic reflexes of the same phonological set (cf. among others Destaing 1920, Appelgate 1970 and Guerssel 1986). ${ }^{20}$

Returning to the imperfective of monoconsonantal verbs, many linguists discuss lexical idiosyncrasy since some verbs change completely ( $u t \rightarrow k k a t$ ) while others use unusual infixes $\left(\iint \rightarrow \int t t a\right)$. My claim does not concern the origin of such affixes or other changes in the form. Rather, I show that the size of their imperfective depends on their base: the shorter the base is, the more numerous the operations used to transform the verb are. This idea seems to lead us toward a template-based explanation of these phenomena. It appears that the verbs in (26) form their imperfective with the same template as triconsonantal verbs, similar to (15). A short verb like $g$ 'be, become' must use all operations possible to fill a template with four CV units, while a triconsonantal verb such as $n k r$ 'stand up' merely geminates its medial consonant. Below are represented some of the verbs in (26) with some bi- and triconsonantal verbs, using the template given in (15).

\footnotetext{
${ }^{20}$ The underlying form of verbs with high vowels relates to the question of the segmental content of the root in Berber. There is no consensus as to the content of the root in Berber. Some (Basset 1929, Cantineau 1950 and Galand 1988) conceive the root as the minimal meaningful unit, entirely composed of consonants, while vowels have a grammatical role. Others, mostly working within the generative tradition (see also Kossman 1997:130) claim that in certain cases, consonants and vowels should not be separated as they share lexical information.
} 
(27)
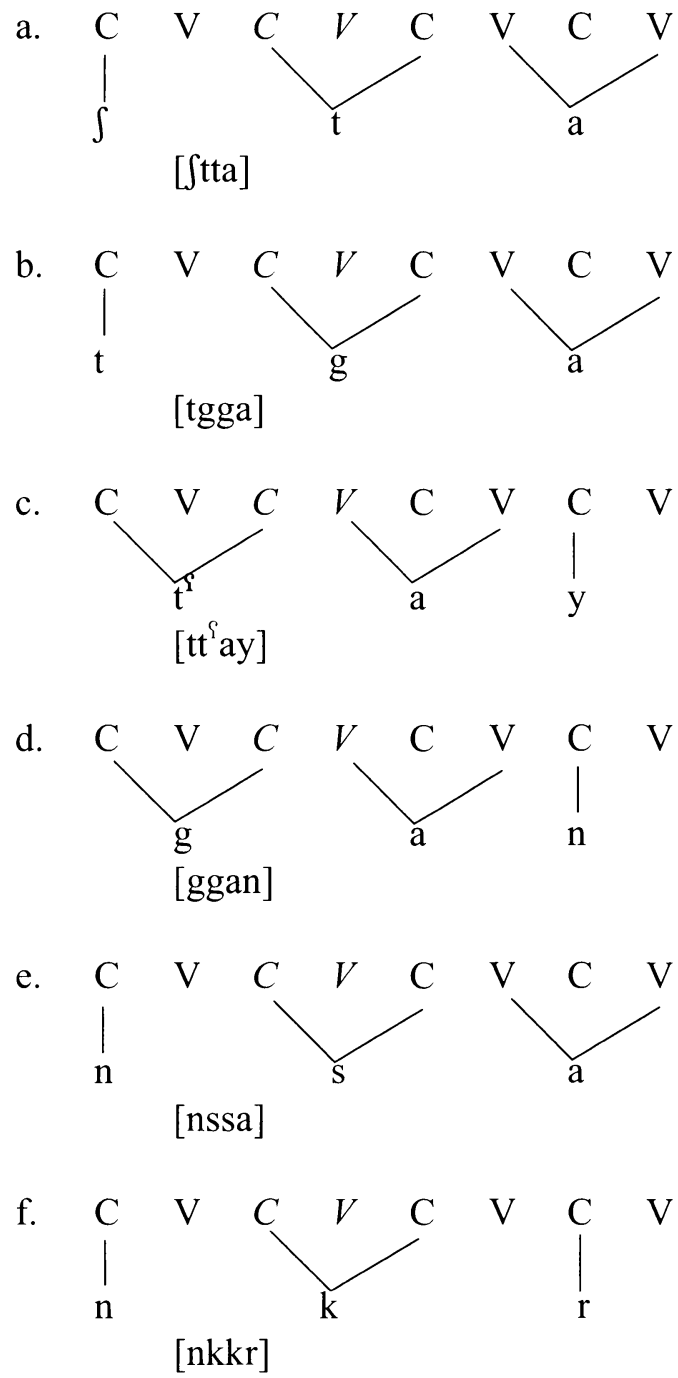

No segregation between consonants and vowels is assumed in the representations above. ${ }^{21}$ That is, consonants and vowels connect to the template at the same level.

\footnotetext{
${ }^{21}$ Unless an argument is made that Berber displays Semitic-like roots, entirely composed of consonants, we maintain that the root in Tashlhiyt Berber may contain consonants and vowels as well (see footnote 20). This allows us to prevent certain problems related to the direction of associations, which would have risen if consonants and vowels are associated separately to the template.
} 


\section{Geminated Imperfective in Other Berber Languages.}

The templatic account of gemination as suggested in Tashlhiyt Berber can be easily generalized to other Berber languages. All Berber languages which use gemination as an imperfectivizing mechanism geminate one root consonant. Gemination in the imperfective is also found in Semitic languages such as Ge'ez (cf. Gragg 1997 and 2004) and Akkadian (cf. Kouvenberg 1997). Many other languages outside of the Afroasiatic family use gemination as a morphological operation: e.g. Alabama and Choctaw (Muskogean family), Balangao and Keley-I (Austronesian family). The reader is referred to Samek-Lodovici (1992) and references therein.

However, while Tashlhiyt Berber geminates either the initial or the medial consonant, the remaining languages invariably geminate the medial consonant. Thus for example, a verb like $k r z$ 'plough' geminates the medial consonant $/ \mathrm{r} /$ in the imperfective in all Berber languages except in Tashlhiyt where it is the first consonant $/ \mathrm{k} /$ that is geminated. In parallel, a verb like $\mathrm{lkm}$ 'arrive' geminates its medial consonant $/ \mathrm{k} /$ in all Berber varieties including Tashlhiyt. Another example is lmad 'learn', which forms its imperfective as lammad in Tarifit (cf. Kossmann 1997 and 2000) and lammæd in Tamashek (cf. Heath 2004). Further examples from Kabyle, Tamazight, Tamashek and Tarifit ${ }^{22}$ are given in the table below.

a. Kabyle (Naït-Zerrad 1994)

Aorist Imperfective

frən farron 'choose'

kroz kərrəz 'plough'

xðəm xəddəm 'work'

brəc bərrəc 'crush'

bzəg bəzzəg 'make swell'

gdəl gaddəl 'forbidden' b. Tamazight (Iazzi 1991)

Aorist Imperfective

nkər nəkkər 'stand up'

krəm kərrəm 'get cold'

$\mathrm{k}^{\mathrm{w}} \operatorname{mad} \mathrm{k}^{\mathrm{w}}$ əmməd 'burn'

krəz kərrəz 'plough'

kməz kəmməz 'scratch'

zləf zolləf 'be grilled'

\footnotetext{
${ }^{22}$ Tamazight and Tarifit are spoken in Morocco. Kabyle is spoken in north-east Algeria. Tamashek is spoken in north Mali.
} 
c. Tamashek ( Heath 2004)

Aorist Imperfective

ว̀lməd lámmæd 'learn'

ว̀lkəm lákkæm 'follow'

ว̀rgəh rággæh 'walk'

ว̀zræw zárræw 'get'

ว̀knəs kánnæs 'fight'

ว̀hlək hállæk 'destroy' d. Tarifit (Kossman 2000) Aorist Imperfective

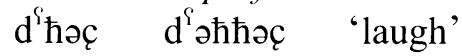
lməd ləmməd 'learn' rbu robbu 'carry' kri kərri 'rent' nkər nəkkər 'stand up' cras carras 'tie, knot'

Apart from Tashlhiyt, which is sensitive to sonority in choosing the consonant candidate for gemination, all Berber languages show a fixed geminated consonant. Rather than stating a language-particular analysis, I suggest that in all Berber languages, including Tashlhiyt, gemination is performed through the use of the same template as stated in (15). In most cases, it is the medial consonant that spreads. Otherwise, it is the first consonant. The imperfective forms mentioned above are all represented in the same manner as $n k k r$ 'stand up' in (16). In addition, mono- and biconsonantal verbs behave in a templatic fashion across Berber languages. They use various morphological operations to form their imperfective, including the gemination of one consonant or affixation, and sometimes both of them. In terms of templatic analysis, these verbs use the same template as triconsonantal verbs, which they fill by means of both gemination and affixation. The following examples in Tamashek (cf. Heath 2004) illustrate this point.

Imperative Long Imperfective

Positive

\begin{tabular}{|c|c|c|}
\hline æ̀bs & báss & 'vomit' \\
\hline$\grave{æ} t^{\mathrm{f}} \mathrm{f}$ & $d^{\text {Y’́fff }}$ & 'be poured' \\
\hline æ̀lh & háll & 'weep' \\
\hline æ̀n & náss & 'excuse' \\
\hline ækk & t-ákk & 'go to' \\
\hline $\mathrm{k}$ J & tátt & 'eat' \\
\hline $\mathrm{nn}$ & jánn & 'say' \\
\hline
\end{tabular}

Three morphological strategies are observed in long imperfective positive forms: 
i. insertion of /a/ after $\mathrm{C}_{1}$ and gemination of $\mathrm{C}_{2}$ (e.g. báss, d'áff, háll, ná $\left.\int\right)$

ii. addition of $/ \mathrm{t}-/$ prefix, then insertion of $/ \mathrm{a} /$ after the prefix (e.g. $t$-ákk)

iii. replacement of the prefix $/ \mathrm{t}-/$ by an apparent epenthetic $/ \mathrm{j}-/$ (e.g. jánn, tátt) followed by an infixed/a/ and a geminated consonant.

All enumerated operations above are traditionally analysed as being idiosyncratic. Under a templatic approach, these operations are used to fill the whole template in the imperfective. In addition, the imperative vs. long imperfective positive derivation shows a vocalic ablaut that replaces the input $/ \mathfrak{a} /$ by an $/ a /$ in the imperfective. $/ \mathfrak{a} /$ is analysed in the Tamashek vocalic system as a short vowel, whereas /a/ is a full vowel. Below in (30) three derivations illustrate the templatic behaviour of mono- and biconsonantal verbs in Tamashek.

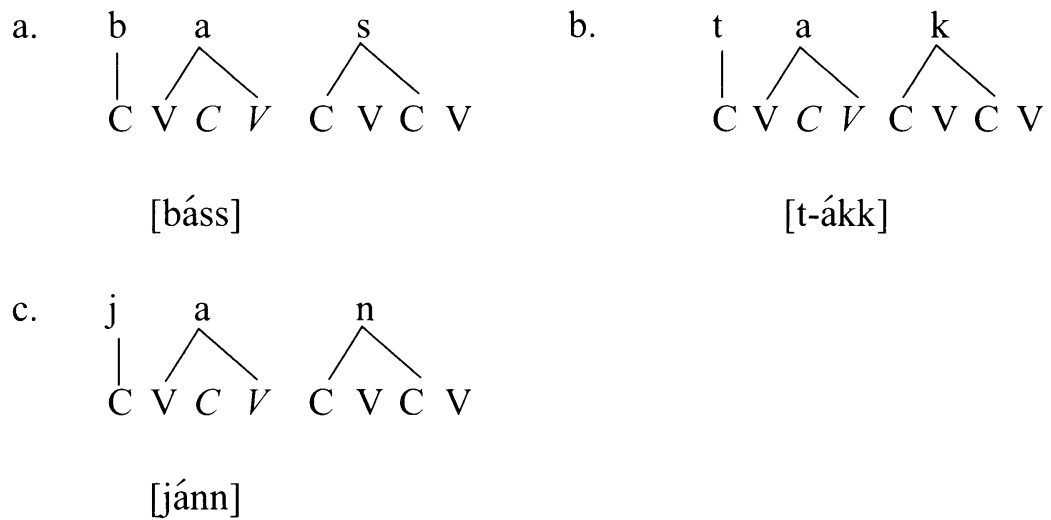

In a biconsonantal verb such as (30a), the imperfective template is filled by means of vowel insertion and consonant lengthening. In contrast, monoconsonantal verbs as in (30b) and (30c) use prefixation in addition to vowel insertion and $\mathrm{C}_{2}$ spreading.

\section{Conclusions.}

This paper has been an attempt to provide a new analysis of geminated imperfective in Tashlhiyt Berber. I have proposed that the triconsonantal verbs which geminate one root consonant to form their imperfective use a fixed-shape template of the form CVCVCVCV. I have also argued that irregular verbs (monoand biconsonantals) derive their imperfective by means of the same template. Their derived forms combine more than one morphological operation (gemina- 
tion, vowel insertion, prefixation and epenthesis) in order to fill the whole template offered by the imperfective formation. The templatic approach to geminated imperfective is then generalized to other languages, including Tamashek, Tarifit, Tamazight and Kabyle.

\section{Appendix}

The data below were collated from various sources including El Mountassir (2003), Boumalk (2003) and Dell \& Elmedlaoui (1988).

\section{Verbs Geminating $\mathrm{C} 2$}

\section{Triconsonantals}

Aorist Imperfective

bdr bddr 'mention'

bxl bxxl 'be stingy'

bsr bssr 'spread'

bzr bzzr 'pluck'

$d^{\text {iff }} \quad d^{\text {iffr }}$ 'follow'

fsr fssr 'spread'

$\mathrm{ftl} \mathrm{fttl}$ 'roll'

$\hbar s r^{\uparrow} \quad \hbar s s r^{i} \quad$ 'stop'

$\mathrm{g}^{\mathrm{w}} \mathrm{mr} \quad \mathrm{g}^{\mathrm{w}} \mathrm{mmr}$ 'fish'

gzm gzzm 'cut'

gzr gzzr 'slaughter (animal)'

bdr bddr 'mention'

$\mathrm{k} \int \mathrm{m} \quad \mathrm{k} \iint \mathrm{m}$ 'enter'

$\mathrm{xmr} \quad \mathrm{xmmr}$ 'ferment'

xsr xssr 'be damaged'

$x t l \quad x t t l \quad$ 'feint'

xzr xzzr 'look nastily'

$\mathrm{zhr}$ zhhr 'blaze up'

С ${ }^{\mathrm{w}} \mathrm{bn} \quad \mathrm{B}^{\mathrm{w}} \mathrm{bbn}$ 'lash'

sml smml 'mould'

$3 \mathrm{dr} \quad 3 \mathrm{ddr}$ 'burn'

lgr lggr 'knock'
Aorist Imperfective

mgr mggr 'harvest'

$\mathrm{md}^{\mathrm{i}} \mathrm{l} \mathrm{mtt}^{\mathrm{i}} \mathrm{l}$ 'bury'

msl mssl 'plug'

nkr nkkr 'stand up'

ndr nddr 'suffer'

$n d^{i} r \quad n t t^{i} r \quad$ 'jump'

nfr nffr 'blow one's nose'

nsr nssr 'graze'

$n t l \quad n t t l$ 'take shelter'

nzl nzzl 'prick'

n3m n33m 'remain unharmed'

rdm rddm 'demolish'

$\mathrm{rd}^{\circledR} \mathrm{ltt} \mathrm{rt}^{\circledR} \mathrm{l}$ 'borrow'

rgl rggl 'knock'

rgm rggm 'insult'

$\mathrm{r}^{\text {S}} \mathrm{m} \quad \mathrm{r}^{\mathrm{i}} \iint \mathrm{m}$ 'mark'

$\mathrm{rkm}$ rkkm 'rot'

rwl rwwl 'flee'

$z^{i} b r \quad z^{i} b b r \quad$ 'prune'

zdm zddm 'gather firewood'

zdr zddr 'lower'

zgr zggr 'go across'

bri brri 'scratch' 


\begin{tabular}{|c|c|c|c|c|c|}
\hline bsi & bssi & 'melt' & dru & drru & 'eat together' \\
\hline dhi & $\mathrm{d} \hbar \hbar \mathrm{i}$ & 'push' & fru & frru & 'pay off' \\
\hline fsi & fssi & 'melt, dissolve' & fsu & fssu & 'vegetate' \\
\hline gli & glli & 'push' & $\mathrm{ftu}$ & $\mathrm{fttu}$ & 'walk, go' \\
\hline $\mathrm{g}^{\mathrm{w}} \mathrm{mi}$ & $\mathrm{g}^{\mathrm{w}} \mathrm{mmi}$ & 'read slowly' & gnu & gnnu & 'sew' \\
\hline gzi & gzzi & 'vaccinate' & gru & grru & 'collect' \\
\hline hri & hrri & 'be toughless' & 3lu & 3llu & 'loose' \\
\hline $\mathrm{k}^{\mathrm{w}} \mathrm{li}$ & $\mathrm{k}^{\mathrm{w}} 11 \mathrm{i}$ & 'tint, blacken' & slu & sllu & 'be expensive' \\
\hline $\mathrm{kmi}$ & $\mathrm{kmmi}$ & 'smoke' & smu & smmu & 'dyed' \\
\hline kti & $\mathrm{ktti}$ & 'blaze up' & Swu & $\int w w u$ & 'toast' \\
\hline $\mathrm{k}^{\mathrm{w}} \mathrm{ti}$ & $\mathrm{k}^{\mathrm{w}} \mathrm{tti}$ & 'remember' & $\hbar b u$ & ћbbu & 'hide' \\
\hline kri & krri & 'shrink' & $\hbar s u$ & hssu & 'learn' \\
\hline ldi & lddi & 'pull' & $\hbar \int u$ & $\hbar \iint u$ & 'stick, shove' \\
\hline mdi & mddi & 'trap' & xlu & xllu & 'destroy, be \\
\hline $\operatorname{md}^{i} \mathrm{i}$ & $\operatorname{mdd}^{\complement} \mathrm{i}$ & 'taste' & & & insane' \\
\hline msi & mssi & 'be tepid' & $\mathrm{kbu}$ & $\mathrm{kbbu}$ & 'pierce' \\
\hline mzi & mzzi & 'mill, grind' & $\mathrm{kd}^{\mathrm{i}} \mathrm{u}$ & $\operatorname{kdd}^{\mathrm{S}} \mathrm{u}$ & 'smell' \\
\hline nfi & nffi & 'jostle, shove' & knu & knnu & 'lean over' \\
\hline ngi & nggi & 'pour' & kru & krru & 'rent' \\
\hline rwi & rwwi & 'soil' & mdu & mddu & 'loose weight' \\
\hline rii & rSSi & 'mix' & ndu & nddu & 'strain' \\
\hline$r z^{i} i$ & $\operatorname{rzz}^{\uparrow} \mathrm{i}$ & 'thread' & $\mathrm{nd}^{\mathrm{i}} \mathrm{u}$ & $n t t^{i} \mathrm{u}$ & ‘jump’ \\
\hline xsi & xssi & 'be extinct' & nru & nrru & 'defeat' \\
\hline zbi & zbbi & 'hasten' & $\mathrm{rbu}$ & rbbu & 'carry on the back' \\
\hline$z^{i} w i$ & $z^{\uparrow} w w i$ & 'left-handed' & rku & rkku & 'be dirty' \\
\hline bdu & bddu & 'start' & rzu & rzzu & 'crawl' \\
\hline$b d^{i} u$ & $\operatorname{bdd}^{i} u$ & 'divide' & sdu & sddu & 'be side by side \\
\hline bgu & bggu & 'pierce' & & & with something' \\
\hline bnu & bnnu & 'build' & zru & zrru & 'delouse' \\
\hline dlu & dllu & 'soak' & $\mathrm{zwu}$ & zwwu & 'dry' \\
\hline
\end{tabular}

\section{Biconsonantals}

Aorist Imperfective

\begin{tabular}{|c|c|}
\hline klla & 'spend the day' \\
\hline kssa & 'graze' \\
\hline$z^{\oint} \mathrm{mma}$ & 'wring' \\
\hline$z^{i} \mathrm{rra}$ & 'see \\
\hline lssa & 'wear' \\
\hline
\end{tabular}

Aorist Imperfective

$\begin{array}{lll}\text { ns } & \text { nssa } & \text { 'stay overnight' } \\ \text { nь } & \text { nqqa } & \text { 'kill' } \\ \text { nz } & \text { nzza } & \text { 'be sold' } \\ \text { rв } & \text { rqqa } & \text { 'be lightened, hot' } \\ \mathrm{rz}^{\text {' }} & \text { rzz'a } & \text { 'break' }\end{array}$




\section{Verbs Geminating C1}

\section{Triconsonantals}

Aorist Imperfective

frd ffrd 'nibble'

frk ffrk 'guess'

frg ffrg 'enclose'

frf ffr 'deceive'

frn ffrn 'pick over'

frs ffrs 'be sharp'

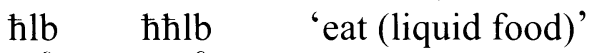

$\hbar r^{i} g \quad \hbar \hbar r^{i} g$ 'burn'

hrm $\hbar r m$ 'ignore'

$\hbar r^{\text {i }} \hbar \hbar r^{i} S$ 'be rough'

hrd hhrd 'eat entirely'

$\operatorname{hr} \operatorname{hhr}$ 'feel slightly ill'

xrb xxrb 'scratch'

$x^{\mathrm{w}} \mathrm{m}_{3} \quad \mathrm{xx}^{\mathrm{w}} \mathrm{m}_{3} \quad$ 'scratch'

xng xxng 'choke'

$\operatorname{rrd}^{\text {i }}$ въrd' 'lie down'

kls kkls 'slash (meat)'

kms kkms 'hold in the hand'
Aorist Imperfective

$\mathrm{k}^{\mathrm{w}} \mathrm{ms} \quad \mathrm{kk}^{\mathrm{w}} \mathrm{ms} \quad$ 'tie into a neat

$\mathrm{k}^{\mathrm{w}} \mathrm{mz} \quad \mathrm{kk}^{\mathrm{w}} \mathrm{mz} \quad \begin{gathered}\text { bundle' } \\ \text { 'scrape' }\end{gathered}$

knd kknd 'dupe'

krz kkrz 'plough'

krf kkrf 'tie'

krm kkrm 'be dried out'

krs kkrs 'tie'

$\mathrm{krd}^{\uparrow} \quad \mathrm{kkrd}^{\text {' }} \mathrm{comb}$ '

brs qqrs 'slaughter'

'ns $^{\uparrow}$ вьns' 'lose a bad habit'

qlb qqlb 'knock out'

$\mathrm{qrs}^{\uparrow} \quad \mathrm{qqrs}^{\uparrow} \quad$ 'reopen (wound),

smd ssmd 'add'

srg ssrg 'have a miscar-

trm ttrm 'shimmy down'

zlf zzlf 'singe'

$z^{i} \operatorname{lm} \quad z z^{i} \operatorname{lm} \quad$ 'peel'

\section{Biconsonantals}

Aorist Imperfective

dl ddal 'cover'

fl ffal 'leave'

gn ggan 'sleep'

$d^{\complement} r \quad t^{\complement}$ ar 'fall down'

gl ggal 'dry up'
Aorist Imperfective

$\mathrm{ml}$ mmal 'show'

$\mathrm{zd}^{\text {' }} \mathrm{zzad}^{\complement} \quad$ 'mill, grind'

rg rrag 'grind, stone'

bZ qqaz 'dig'

sь ssaь 'buy' 


\section{REFERENCES}

Anderson, John. 1985. "Structural analogy and dependency phonology". Acta Linguistica Hafniensia 19: 05-44.

Anderson, John. 2002. A Notational Theory of Syntactic Categories. Cambridge Studies in Linguistics 82. Cambridge: Cambridge University Press.

Anderson, John \& Ewen, Colin. 1987. Principles of Dependency Phonology. Cambridge: Cambridge University Press.

Angoujard, Jean-Pierre. 1990. Metrical structure of Arabic. Berlin, New York: Mouton de Gruyter.

Appelgate, Joseph R. 1970. "The Berber Languages". Current Trends in Linguistics 6: Linguistics in South West Asia and North Africa, ed. by Thomas A. Sebeok, Charles A. Ferguson, Carleton T. Hodge, Herbert H. Paper, John R. Krueger \& Gene M. Schramm. The Hague: Mouton. Pp. 586-661.

Banksira, Degif Petros. 1999. "Chaha Subject Affixes as Two Independent Heads", MIT Working Papers in Linguistics 33, ed. by Karlos Arregi, Benjamin Bruening, Cornelia Krause \& Vivian Lin. Cambridge, Massachusetts: MIT. Pp. 27-45.

Basset, André. 1929. La langue berbère. Morphologie. Le verbe: étude de thèmes. [2004 ed.]. Paris: L'Harmattan.

Bauer, Hans \& Pontius Leander.1922. Historische Grammatik der hebräischen Sprache des Alten Testamentes. Halle a. S.: Verlag von Max Niemeyer.

Bendjaballah, Sabrina. 1999. Trois figures de la structure interne des gabarits: activité morphologique $d u$ niveau squelettal des représentations phonologiques en berbère, somali et bedja. Paris: Université Paris 7, PhD. dissertation.

Bendjaballah, Sabrina. 2001, “The « Negative Preterit » in Kabyle Berber". Folia Linguistica XXXIV/3-4: 185-220. 
Bendjaballah, Sabrina \& Martin Haiden. 2003. "Templatic Architecture". Recherches Linguistiques de Vincennes 32: 157-168.

Bendjaballah, Sabrina \& Martin Haiden. 2005. The Grammar of Prepositions in Berber. Ms. University Lille 3.

Bensoukas, Karim. 2001. Stem forms in the Nontemplatic Morphology of Berber. Rabat: Mohamed V University, Doctorat d'Etat Thesis.

Boumalk, Abdallah. 2003. Manuel de conjugaison du tachelhit (langue berbère $d u$ Maroc). Paris: L'Harmattan.

Cantineau, Jean. 1950. “Racines et schèmes”. Mélanges William Marçais. Paris: Maisonneuve. Pp. 119-124.

Chomsky, Noam. 1970. "Remarks on Nominalization". Readings in English Transformational Grammar, ed. by Roderick A. Jacobs \& Peter S. Rosenbaum. Waltham, MA: Ginn and Co. Pp. 184-221.

Clements, George N. 1990. "The role of the sonority cycle in core syllabification". Papers in Laboratory Phonology 1: Between the grammar and physics of speech, ed. by John Kingston and Mary Beckman. New York: Cambridge University Press. Pp. 283-333.

Coleman, John. 1996. "Declarative Syllabification in Tashlhiyt Berber", Current Trends in Phonology: Models and Methods. Volume 1, ed. by Jacques Durand \& Bernard Laks. Salford: European Studies Research Institute, University of Salford. Pp. 175-216.

Coleman, John. 2001. "The phonetics and phonology of Tashlhiyt Berber syllabic consonants". Transactions of the Philological Society 99: 29-64.

Davis, Stuart. 1995. "Geminate consonants in moraic phonology". West Coast Conference on Formal Linguistics 13: 32-45.

Davis, Stuart. 1999. “On the representation of initial geminates". Phonology 16: 93-104. 
De Chene, E. Brent \& Stephen R. Anderson. 1979. "Compensatory Lengthening". Language 55: 505-535.

Dell, François \& Mohamed Elmedlaoui. 1988. "Syllabic Consonants in Berber: Some New Evidence". Journal of African Languages and Linguistics 10: 117.

Dell, François \& Mohamed Elmedlaoui. 1991. "Clitic Ordering, Morphology and Phonology in the Verbal Complex of Imdlawn Tachlhiyt Berber". [Part II]. Langues Orientales Anciennes Philologie et Linguistique 3: 77-104.

Dell, François \& Mohamed Elmedlaoui. 1992. "Quantitative Transfer in the Nonconcatenative Morphology of Imdlawn Tashlhiyt Berber". Journal of AfroAsiatic Languages 3: 89-125.

Dell, François \& Mohamed Elmedlaoui. 2002. Syllables in Tashlhiyt Berber and in Moroccan Arabic. Dordrecht: Kluwer Academic Publisher.

Destaing, Edmond. 1920. Etude sur le dialecte berbère des Ait Seghrouchen. Paris: Editions Ernest Leroux.

Dwyer. David. 1978. "What Sort of Tone Language is Mende?". Studies in African Linguistics 9:167-208.

El Mountassir, Abdallah. 2003. Dictionnaire des verbes tachelhit-francais (parler berbère du sud du Maroc). Paris: L'Harmattan.

Galand, Lionel. 1988. "Le berbère". Langues dans le monde ancien et moderne, vol. III, ed. by Daniel Coghen \& Jean Perrot. Paris: CNRS. Pp. 207-242.

Gragg, Gene. 1997. “Ge'ez (Ethiopic)”. The Semitic Languages, ed. by Robert Hetzron. London: Routledge. Pp. 242-262

Gragg, Gene. 2004. “Ge'ez (Aksum)”. The Ancient Languages of Mesopotamia, Egypt and Aksum, ed. by Roger D. Woodward. Cambridge: Cambridge University Press. Pp. 211-237. 
Gesenius, Wilhelm. 1881. Hebräische Grammatik. Leipzig: Verlag von F.C.W. Vogel.

Guerssel, Mohamed. 1986. "Glides in Berber and Syllabicity". Linguistic Inquiry 17-1: 1-12.

Guerssel, Mohamed. 1992. "The Phonology of Berber Derivational Morphology by Affixation". Linguistic Analysis 22: 3-60.

Guerssel, Mohamed \& Jean Lowenstamm. 1990. The Derivational Morphology of the Classical Arabic Verbal System. Ms. UQAM \& Université Paris 7.

Hammond, Michael. 1984. Constraining Metrical Theory: a Modular Theory of Rhythm and Destressing. UCLA, Ph.D. dissertation.

Hayes, Bruce. 1989. “Compensatory Lengthening in Moraic Phonology". Linguistic Inquiry 20: 253-306.

Heath, Jeffrey. 2004. Grammar of Tamashek (Tuareg of Mali). Ms. University of Michigan.

Hoberman, Robert D. 1988. "Local and Long-distance Spreading in Semitic Morphology". Natural Language and Linguistic Theory 6: 541-549.

Iazzi, EL Mehdi. 1991. Morphologie du verbe en tamazight (parler des Aït Attab, Haut Atlas Central): approche prosodique. Rabat: University Mohamed V, D.E.S. Thesis.

Idrissi, Ali. 2000. "On Berber Plurals". Research in Afroasiatic Grammar, ed. by Jacqueline Lecarme, Jean Lowenstamm \& Ur Shlonsky. Amsterdam: John Benjamins. Pp. 101-124.

Ingria, Robert. 1980. "Compensatory Lengthening as a Metrical Phenomenon". Linguistic Inquiry 11: 465-495.

Jebbour, Ahmed. 1988. Processus de formation du pluriel nominal en tamazight (tachelhit de Tiznit) — approche non-concatenative. Rabat: Université Mohammed V, D.E.S. Thesis. 
Jebbour, Ahmed. 1996. Morphologie et contraintes prosodiques en berbère (tachelhit de Tiznit) : analyse linguistique et traitement automatique. Rabat: Université Mohamed V, Doctorat d'Etat Thesis.

Jebbour, Ahmed. 1999. "Syllable Weight and Syllable Nuclei in Tashlhiyt Berber of Tiznit." Cahiers de Grammaire 24: 95-116.

Jespersen, Otto. 1904. Lehrbuch der Phonetik. Leipzig and Berlin: B. G. Teubner.

Kabbaj, Ouadia. 1990. La structure syllabique de l'arabe marocain. Montréal: UQAM, MA thesis.

Kaye, Jonathan. 1990. "Government in Phonology: the Case of Moroccan Arabic". The Linguistic Review 6: 131-159.

Kaye, Jonathan, Jean Lowenstamm \& Jean-Roger Vergnaud. 1985. "The Internal Structure of Phonological Elements: A Theory of Charm and Government". Phonology Yearbook 2: 305-328.

Kaye, Jonathan, Jean Lowenstamm \& Jean-Roger Vergnaud. 1990. "Constituent Structure and Government in Phonology”. Phonology 7: 193-231.

Kenesei, Istvàn, Robert M. Vago \& Anna Fenyvesi. 1998. Hungarian, New York: Routledge.

Kihm, Alain. 2006. "Nonsegmental Concatenation: A Study of Classical Arabic Broken Plurals and Verbal Nouns". Morphology 16: 69-105.

Kossmann, Maarten. 1997. Grammaire berbère de Figuig (Maroc oriental). Paris-Louvain: Peeters.

Kossmann, Maarten. 2000. Esquisse grammatical du rifain oriental. Peeters: Paris-Louvain.

Kossmann, Maarten. 2002. "L'origine de l'aoriste intensif en berbnre". Bulletin de la Société de Linguistique de Paris, tome XCVII, fascicule 1: 353-370. 
Kossmann, Maarten. 2003. "The origin of the Glottal Stop in Zenaga and its Reflexes in the other Berber Languages". Africa und Übersee 84-1 [2001]: 61100 .

Kouvenberg, Norbert J.C. 1997. Gemination in the Akkadian verb. Studia Semitica Neerlandica, Van Gorcum: The Netherlands.

Lahrouchi, Mohamed. 2003. "Manifestations gabaritiques dans la morphologie verbale du berbère (parler chleuh d'Agadir) ". Recherches Linguistiques de Vincennes 32: 61-82.

Louali, Naima and Gérard Philippson. 2003. "Le thème de l'aoriste intensif: formes multiples, contenu unique". Collection d'articles $2^{\text {nme }}$ Bayreuth Frankfurter Kolloquium zur Berberologie. Berber Studies, Rüdiger Köppe Verlag. Pp. 79-94.

Lowenstamm, Jean. 1991. "Vocalic Length and Centralization in Two Branches of Semitic (Ethiopic and Arabic)". Semitic Studies in Konor of Wolf Leslau on the Occasion of his Eighty-fifth Birthday, ed. by Alan S. Kaye. Wiesbaden: Otto Harrassowitz. Pp. 949-965

Lowenstamm, Jean. 1996. "CV as the only syllable type", Current Trends in Phonology: Models and Methods, Volume 2, ed. by Jacques Durand and Bernard Laks. Salford: European Studies Research Institute, University of Salford. Pp. 419-441.

Lowenstamm, Jean. 2003. "A propos des gabarits". Recherches Linguistiques de Vincennes 32: 7-30.

Lowenstamm, Jean \& Jonathan Kaye. 1986. "Compensatory lengthening in Tiberian Hebrew". Studies in Compensatory Lengthening, ed. by Leo Wetzels \& Engin Sezer. Dordrecht: Foris. Pp. 97-133.

Lumsden, John \& Girma Halefom. 2003. "Verb Conjugations and the Strong Pronoun Declension in Standard Arabic". Research in Afroasiatic Grammar II, ed. by Jacqueline Lecarme. Amsterdam: John Benjamins. Pp. 305-337. 
MacBride, Alexander. 2004. A Constraint Based Approach to Morphology. UCLA, Ph.D. dissertation.

McCarthy, John. 1979. Formal Problems in Semitic Phonology and Morphology. MIT, PhD. dissertation. Distributed by Indiana University Linguistics Club.

McCarthy, John. 1981. "A Prosodic Theory of Nonconcatenative Morphology". Linguistic Inquiry 12: 373-418.

Meillet, Antoine and Vendryes, Joseph. 1963. Traité de grammaire comparée des langues classiques. [ $3^{\text {rd }}$ edition]. Paris: Champion.

Moktadir, Khalid. 1989. The Passive Form in Tashlhiyt Berber - A Prosodic Approach. Rabat: Université Mohammed V, D.E.S. Thesis.

Naï-Zerrad, Kamal. 1994. Manuel de conjugaison kabyle. Paris: L'Harmattan.

Odden, David. 1988. “Anti Antigemination and the OCP”. Linguistic Inquiry 19: 451-475.

Prasse, Karl G. 1972. Manuel de grammaire touarègue (tahaggart). Copenhagen: Akademisk Forlag.

Prince, Alan. 1985. "Improving Tree Theory". Proceedings of Berkeley Linguistic Society 11, ed. by Mary Niepokuj et al. Berkeley: BLS. Pp. 471-490.

Puech, Gilbert \& Naima Louali. 1999. "Syllabification in Berber: The Case of Tashlhiyt". Proceeding of the 14 International Congress of Phonetic Sciences. San Fransisco. Pp. 747-750

Ridouane, Rachid. 2003. Suites de consonnes en berbère: phonétique et phonologie. Paris: University Paris 3, PhD. dissertation.

Rucart, Pierre. 2006a. Morphologie gabaritique et interface morphosyntaxique. Paris: University Paris 7, PhD. dissertation. 
Rucart, Pierre. 2006b. "Templates from Syntax to Morphology: Affix Ordering in Qafar”. ExLing-2006, ed. by Antonis Botinis. Athens: University of Athens. Pp. 213-216.

Saib, Jilali. 1976. A Phonological Study of Tamazight Berber: Dialect of the Ayt Ndhir. UCLA, PhD. dissertation.

Samek-Lodovici, Vieri. 1992. "A unified analysis of crosslinguistic morphological gemination". Proceedings of CONSOLE-1, ed. by Peter Ackema \& Maaike Schoorlemmer. The Hague: Holland Academic Graphic. Pp. 265-283.

Scheer, Tobias. 2004. A Lateral Theory of Phonology: What is CVCV and Why Should it Be? Berlin and New York: Mouton de Gruyter.

Sezer, Engin. 1986. "An Autosegmental Analysis of Compensatory Lengthening in Turkish". Studies in Compensatory Lengthening, ed. by Leo Wetzels \& Engin Sezer. Dordrecht: Foris. Pp. 227-250.

Sibawayh. 1983 ed. Alkitaab. Beirut, Lebanon: Aalam alkutub.

Sievers, Eduard. 1881. Grundzüge der Phonetik. Leipzig: Breitkopf and Hartel.

Yip, Moira. 1988. "Template Morphology and the Direction of Association". Natural Language and Linguistic Theory 6: 551-577.

UMR 7023 - Structures Formelles du Langage

2 rue de la Liberté

93526 SAINT-DENIS Cedex France

Mohamed.Lahrouchi@univ-paris8.fr [received October 1, 2004, accepted July 29, 2008] 